\title{
Developing a Web-based agricultural community information centre for rural farmers
}

\author{
Zacharia Letshela \\ University of the North Library, Private Bag X1112, Sovenga, 0727 South Africa \\ LETSHELAZ@unin.unorth.ac.za>
}

\section{Contents}

Introduction

Features (characteristics of rural communities)

Information needs of rural farmers

Methods used to provide information to rural farmers

Web-based community center

Conclusion

$\underline{\text { References }}$

\section{Introduction}

Frank (1987:320) maintains that the greatest challenge facing the agricultural sector is the delivery of useful information to rural communities. In the same vein, Van Niekerk (1993:19) sees one of the ways of improving production in agriculture as the reduction of the gap between theory and practice. The gap between theory and practice can only be reduced if correct methods of communication are implemented. These methods should be able to support both direct and indirect communication. By direct communication reference is made to a situation where feedback can be provided instantly. Methods such as meetings and farmers' days are some of the examples of this mode of communication. Indirect communication on the other hand, precludes any feedback of information and media such as books and circulars are some of the examples that have been employed in this type of communication. Previously no medium offered an opportunity to utilise both ways of communication. The emergence of the Internet, and more specifically the Web, in the last few years has brought along positive possibilities in terms of combining these two methods of communication. These possibilities are even much more encouraging when the situation in rural communities is taken into consideration, because these areas are constantly plagued by a lack of access to information. Because of its ability to allow for both methods of communication and the relatively cheap costs involved in providing access, the Web is seen as a major development in terms of bridging the information gap. To provide a basis upon which the actual design of a Web-based information centre can take place, it is necessary to first understand the features (characteristics) of rural communities, including those of 
farmers. Without an understanding of the problems that these communities face it will not be possible to provide solutions for them.

\section{Features (characteristics) of rural communities}

Numerous studies have been conducted where the features of rural communities are discussed. To name just a few, studies by Dreenan \& Dreenan (1980), Houlahan (1980) and Nwagha (1992) are some of the studies that document challenges facing rural communities. Dreenan \& Dreenan (1980:493-510) characterise rural communities in the USA as areas where there is a growing population, sparsely distributed families, minority groups, deprived households, short supply of information sources, long distances to travel, remote commercial facilities, lack of proper life support systems, high education-related expenditures, low educational achievements, low family incomes and high voter turnouts.

Similarly, Houlahan (1980:490) identifies one of the problems of rural areas as geographic remoteness. This remoteness manifests itself in various ways, such as remote from information supply sources, social agencies, educational institutions, and business and leisure activities. Besides being remote, rural areas are depicted as places with low population sizes, population density, transportation, poverty and educational levels.

In Africa, Nwagha (1992:76) depicts rural areas as places where people live in scattered and isolated communities that lack electricity, potable water, good roads, hospitals and schools. There is also low employment opportunities in these areas.

An analysis of these studies reveals some similarities even though they have been conducted on different continents. Because of these similarities, it is possible to design a profile of rural communities. Consequently rural areas can be characterised as areas that have no easy access to basic amenities such as schools, hospitals, commercial centres, libraries, parks, cinemas and government offices to name just a few. Since these communities do not have easy access to basic resources, services that are designed for them must consider these shortcomings. For instance, because of a lack of educational facilities, most people in rural areas are not literate and as a result cannot readily take advantage of opportunities that are for example provided by technological developments.

The significance of this information in this paper is therefore that it assists in the process of designing services for these areas. Knowledge of these features guides the manner and form in which for instance information has to be provided. This information is also important in as much as it provides a picture of what the information needs of these communities might be.

\section{Information needs of rural farmers}

Rural farmers in most instances are faced with the same challenges that confront the local population. Most rural farmers especially in Africa are illiterate and poor, and lack the skills to operate computers. Although there are a few who have these skills, they are in the most cases the exception rather than the rule. This groups' presence in rural areas can be attributed to changes in population distribution and background as alluded to by Frank (1987:298).

Not much has been published with regard to the information needs of rural farmers in the USA (Frank 1987:297). The situation is not much different in Africa because according to 
Kaniki (1992:84) '...there is a lack of extensive studies on agricultural information needs'. Besides a study that he conducted in Nigeria, he mentions two other relevant studies conducted in Africa by Ojiambo in Kenya and Ikpaahindi in Nigeria (Kaniki 1992:84).

Notwithstanding this situation, from the few available case studies, consensus seems to emerge about the type of information that this sector has access. In an attempt to provide a comprehensive list of needs of the agricultural sector, Frank (1987:299-300) identifies eight groups of users as belonging to this sector. These groups are policy makers, research scientists, industrial scientists, specialist advisors, extension personnel, educators, agricultural service industries and consumers which include farmers. He further provides a list of needs for each user group. These user groups and their needs are illustrated in Table 1.

Table 1 Information needs of the agricultural sector

\begin{tabular}{|l|l|}
\hline USER POPULATION & INFORMATION NEEDS \\
\hline Policy makers & $\begin{array}{l}\text { Production levels, use of resources, } \\
\text { market outlook, state and national } \\
\text { outlook, }\end{array}$ \\
\hline Research scientists & Research, rapid access to latest findings \\
\hline Industrial scientists & $\begin{array}{l}\text { Immediate access to details of new } \\
\text { standards, techniques and procedures, } \\
\text { patents and product details, trade } \\
\text { information, market intelligence outlook }\end{array}$ \\
\hline Special advisors & Similar to those of research scientists \\
\hline Extension personnel & $\begin{array}{l}\text { Practical information, factual } \\
\text { information, current practices, up-to-date } \\
\text { information }\end{array}$ \\
\hline Educators & $\begin{array}{l}\text { Current practices and issues, computer } \\
\text { literacy and experience in accessing } \\
\text { databases }\end{array}$ \\
\hline Agricultural service industries & $\begin{array}{l}\text { Market trends, production estimates, } \\
\text { prospects for agricultural industries, } \\
\text { research results new practices and } \\
\text { government policy, rapid access to new } \\
\text { information }\end{array}$ \\
\hline Consumers (farmers, ranchers and rural \\
residents) & $\begin{array}{l}\text { Production, marketing and consumption } \\
\text { information, information to manage lives } \\
\text { and cope with everyday problems and } \\
\text { realise opportunities }\end{array}$ \\
\hline
\end{tabular}

In a study of agricultural scientists, Kaniki (1992:85) identifies the following information needs:

- Production techniques and levels

- Use of resources, market outlook

- Research - past, present, and future, with rapid access to latest findings

- New developments and who is conducting research in each researcher's area

- Current practices and issues.

Although these needs do not necessarily refer to farmers they are significant in as far as they establish some commonality in terms of the information needs of the agricultural sector.

A study by Prinsloo (1996) similarly identifies the needs of rural farmers in four main areas, namely: 
- Correct farming techniques

- Planting correct crops

- Correct harvesting methods

- Developing marketing and entrepreneurial skills.

The needs identified by Prinsloo are completely consistent with the ones identified by Frank. As a result, it is possible to conclude that rural farmers have information needs with regard to techniques and methods that would assist them in farming and crop production. They similarly require information that would assist them to harvest and market their products successfully.

\section{Methods used to provide information to rural farmers}

Since the information needs of rural farmers became known, various initiatives have been undertaken to address these needs. To a large extent, these initiatives have been launched as a result of realising the potential benefits that the farming sector has on the economies of most countries. Frank (1987:293), citing the 1986 Department of Agriculture statistics in the USA, identifies the agricultural sector as the biggest industry and the largest employer. Van Niekerk (1993) echoes the same sentiments when she asserts that agriculture is an essential part of the South African economy. Consequently, various initiatives have been undertaken to fulfil the information needs of rural farmers.

Information available in the literature tends to support the view that most initiatives, which have been launched previously to provide information to rural farmers, can be regarded as traditional approaches. Among other things, these approaches encourage the use of colleagues, community leaders, popular press, demonstrations and exhibitions as a way of providing information. To a great extent these approaches have not been successful (Kiplang'at 1998:303).

Because of the lack of success by traditional modes, other approaches are emerging. These approaches are mainly based on the use of technological developments to provide information. Proponents of this approach are of the opinion that information technology is relevant in rural areas since it reduces costs of acquiring information, is relatively easy to use, and can provide faster access. As a result, this technology is seen as addressing some of the challenges faced by rural farmers, such as low-income levels. Some of the technologies already used include CD-ROMS, pocket radio, expert systems, radio and video cassettes. An analysis of these technologies reveals that although they provide reliable information at a reasonable cost, to some extent they still preclude direct communication with users. Some of them might also be outdated when by the time they reach the rural areas. This has fuelled the need for computer networks to be used in providing information.

The emergence of the Internet, and especially the Web, is regarded as an important development with regard to using computer networks. The Web is an improvement over the other modes of communication since information from various sources can be accessed at lower costs, and problems can be posted to experts for prompt responses. It thus supports both direct and indirect communication. The Web also possess both sound and picture abilities, which can be used to further address the problem of illiteracy faced by rural farmers. Attempts are also continuing with regard to using satellite technology to provide access to information but, since not much success has been achieved with implementing this technology, not much is said about it in this paper. Consequently, the rest of this paper deals with the Web as an alternative medium towards providing information services to rural farmers. 


\section{Web-based community centre}

The contribution that this paper wishes to make on this topic concerns issues that must be considered before a successful Web-based information system can be implemented. Based on these issues a possible model is suggested. Consequently aspects like the history and the mechanics of the Web are not discussed since they are well documented elsewhere. Most of the issues discussed are adopted from the literature dealing with community networks, since Web-based community centres are regarded as online versions of these networks.

Information on community networks can be found in abundance in the literature. Much of this literature is generated either from the USA, Europe or Canada (Communities online 1998). From the available literature such as Wicox (1996), Molz (1994) and Morino Institute (1994), there is consensus on aspects that must be considered for proper implementation of community networks. Some of these aspects are identified as:

- Users

- goals

- governance

- staffing

- funding

- technical design

- content

- access

- competitors

- collaborators.

A brief discussion of each element follows.

The element of users refers to identifying people who would make use of the network. It includes having a profile on factors such as sex, level of education, technological expertise, income bracket and age. Also under consideration is the type of information needed and how people go about obtaining it. Related to identifying users is the element of having an wellarticulated goal. It is necessary to determine what the goal of the network is, since this will guide operations of the network. Some of the goals identified in the literature include increasing the sense of community attachment, improved living through access to information, increase citizen participation in government issues, confront problems of connectivity, furthering educational levels, increase citizens technological knowledge and economic betterment of rural people.

Governance on the other hand addresses aspects such as how the day to day operations of the network will be conducted. It relates to aspects like whether a board or a management committee runs the network. Similarly, staffing deals with people who are needed to run the network. For instance, it establishes the number of people and what their skills should be. Also under consideration is whether full-time or volunteer staff should be used.

Funding addresses issues such as what type of funding will be needed to establish and maintain the network. Elements like whether the network will charge subscription fees, use local taxes or rely on grant money for support are also considered. Technical design on the other hand considers factors such as what IT infrastructure, level of Internet connection, telecommunications infrastructure, software, interfaces and system management are necessary. 
Content refers to the type of information that will be provided on the network. It determines whether a network will provide information in a certain field only (special focused) or whether broad information covering many subject areas (general) will be provided. Access addresses questions such as where to place points of access to the network, how easy it is to use the system and if there is any filtering and contextualisation of information on the network. It is important to select places that are well secured and within easy reach by users.

Competitors deal with identifying people or agencies that may be involved in developing other community networks that are targeting the same users. This information is crucial since it will help to decide on the coverage of the network and also help to avoid problems that other networks might have experienced. The last element, namely collaborators, refers to additional people or agencies that might be involved in providing the same services or responding to similar needs. This information will ensure that skills and resources are shared.

An analysis of these elements reveals that without proper consideration of each of them defective systems that do not respond to user needs might be designed. In considering these elements a system that takes note of the needs, level of education, income, computer use and connectivity of areas to be served can be designed.

The model suggested in this paper was designed for a rural area in the Marble Hall area for farmers who had received some training from the Aquaculture Research Unit (ARU). The University of the North (UNIN), as part of its outreach function, could utilise its connectivity levels to provide access to information for these rural farmers. Such a step could help to avoid the exorbitant prices charged by Internet service providers (ISP). Table 2 provides a schematic representation of the suggested model.

Table 2 Suggested model

\begin{tabular}{|l|l|}
\hline \multicolumn{1}{|c|}{ Feature } & \multicolumn{1}{|c|}{ Model } \\
\hline Goals & Farmers in Marble Hall \\
\hline Governance & Users \\
\hline Staffing & $\begin{array}{l}\text { Economic betterment and access to } \\
\text { information sources }\end{array}$ \\
\hline Funding & $\begin{array}{l}\text { Board consisting of ARU, financial } \\
\text { sponsors and community }\end{array}$ \\
\hline Technical design & $\begin{array}{l}\text { Permanent staff member, volunteers } \\
\text { and student assistants }\end{array}$ \\
\hline Content & $\begin{array}{l}\text { Grants and small levies charged for } \\
\text { certain services }\end{array}$ \\
\hline Access & $\begin{array}{l}\text { Dial-in, Web-based access using } \\
\text { telephone lines to gain direct access into } \\
\text { UNIN servers }\end{array}$ \\
\hline Competitors & $\begin{array}{l}\text { ARU publications, periodical literature } \\
\text { and access to other aquaculture sites }\end{array}$ \\
\hline Collaborators & Local school \\
\hline & Telecentre developers \\
\hline & $\begin{array}{l}\text { ARU, Department of Information } \\
\text { Studies, AGRELEK, PEACE } \\
\text { Foundation, extension workers, Northern } \\
\text { Province government and Marble Hall } \\
\text { community }\end{array}$ \\
\hline & \\
\hline
\end{tabular}




\section{Conclusion}

This paper discussed how a Web-based information centre should be designed for rural farmers. The Web was specifically suggested because of the possibilities it provides and advantages that it brings to the communication process over other traditional modes of communication. That the Internet has changed how communication takes place is without doubt. The challenge is for information professionals to design and implement cheaper, more flexible, attention grabbing and less polluting systems that respond rapidly to user needs.

\section{References}

Communities online. 1998. Communities online [online]. Available at http://www.communities.org.uk/home.htm

Dreenan, A. \& Dreenan, H. 1980. Rural populations in the 1970s. Library trends, 28(1):493512.

Frank, R.C. 1987. Agricultural information systems and services. In: M.E. Williams (ed). Annual review of information science and technology. Vol 22. Amsterdam: Elsevier Science Publishing.

Houlahan, J.M. 1980. Introduction (to articles on rural information needs) Library trends, 28 (1):489-492).

Kaniki, A.M. 1992. Meeting the needs of agricultural researchers in Africa: the role of unpublished reports. Information development, 8(2):83-89.

Kiplang'at, J. 1998. An analysis of the opportunities of information technology in improving access, transfer and use of agricultural information in the rural areas of Kenya. In:

Information for sustainable development in the $21^{\text {st }}$ century. Proceedings of the $13^{\text {th }}$ standing conference of Eastern Central and Southern African Librarians. Nairobi: Kenya library association.

Letshela, P.Z. 1999. Rendering information services to rural communities through Web technology. D.Phil. thesis. Johannesburg: Rand Afrikaans University. (Unpublished).

Molz, R.K. 1994. Civic networking in the United States: a report by Columbia university students. Internet research: electronic networking applications and policy, 4(4):52-62. Morino Institute. 1994. Assessment and evolution of community networks. [Online]. Available at http://www.morino.org/ties94sp.html.

Nwagha, G.K.N. 1992. Information needs of rural women in Nigeria. Information development, 8(2):76-82.

Prinsloo, J.F. 1996. Human resource development programme: the Oasis project.

(Unpublished).

Van Niekerk, R.V. 1993. Communication of agricultural information in South Africa. South African journal of library and information science, 61(1):19-27.

Wilcox, D. 1996. Community networks. British telecommunications engineering journal, 14 (4):310-317.

\section{Disclaimer}

Articles published in SAJIM are the opinions of the authors and do not necessarily reflect the opinion of the Editor, Board, Publisher, Webmaster or the Rand Afrikaans University. The user hereby waives any claim he/she/they may have or acquire against the publisher, its suppliers, licensees and sub licensees and indemnifies all said persons from any 
claims, lawsuits, proceedings, costs, special, incidental, consequential or indirect damages, including damages for loss of profits, loss of business or downtime arising out of or relating to the user's use of the Website.

ISSN 1560-683X

Published by InterWord Communications for the Centre for Research in Web-based Applications, Rand Afrikaans University 